\title{
Medial Circumflex Artery
}

National Cancer Institute

\section{Source}

National Cancer Institute. Medial Circumflex Artery. NCI Thesaurus. Code C52965.

An artery arising from the profunda femoris artery with ascending and descending branches that supply the thigh muscles and hip joint. 